\title{
A rare presentation of cleidocranial dysplasia
}

\author{
Ilse Broeks, ${ }^{1}$ Irma E Veenstra-Knol, ${ }^{2}$ Arvid W A Kamps ${ }^{1}$ \\ ${ }^{1}$ Department of Paediatrics, Medical Center Leeuwarden, Leeuwarden, The Netherlands \\ ${ }^{2}$ Department of Genetics, University Medical Center Groningen, Groningen, The Netherlands
}

Correspondence to Dr Arvid W A Kamps, arvid.kamps@znb.nl

\section{Summary}

Cleidocranial dysplasia (CCD) is a rare skeletal dysplasia characterised by a defect in ossification. Frequently reported clinical findings are delayed closure of the fontanelles and cranial sutures, hypoplastic clavicles, dental abnormalities and short stature. Our patient suffered from complete absence of ossification of both parietal bones. This is a rare and severe defect that has been reported in only a few patients with CCD.

\section{BACKGROUND}

Cleidocranial dysplasia (CCD) is an autosomal-dominant skeletal dysplasia affecting intramembranous ossification. The diagnosis of CCD is based on clinical and radiographic findings. In $60-70 \%$ of patients, mutations in the RUNX2 gene are responsible for the clinical picture. ${ }^{1-3}$ Manifestations range from isolated dental anomalies to full-blown disease presenting with poorly ossified cranium and absent clavicles (table 1). ${ }^{4}$

A thorough diagnostic work-up is essential to confirm diagnosis, determine the severity of disease and enable proper counselling by the paediatrician and clinical geneticist. Long-term follow-up is needed by a multidisciplinary team including the paediatrician, dentist and orthopaedic surgeon as more symptoms can become apparent during growth and different stages of childhood.

Based on the experience with this patient and review of the literature, a flowchart is proposed.

\section{CASE PRESENTATION}

We present a firstborn female infant of a nonconsanguineous couple. During routine ultrasound examination in the second trimester, incomplete mineralisation of the skull was found. This finding could not be confirmed during subsequent ultrasonographic examinations. She was born by vaginal delivery at $39+6$ weeks of gestation. Upon examination during labour, a soft presenting body was palpated and a breech presentation was suspected. Her Apgar scores at 1,5 and 10 min were 9,10 and 10, respectively. Birth weight was $3240 \mathrm{~g}$. After birth, the skull had a normal outer appearance with an intact skin but felt soft when palpated. A skull ultrasound revealed no definite abnormalities. Subsequently, a low-dose threedimensional CT scan of the skull was performed and complete absence of ossification of both parietal bones was found (figure 1). This finding prompted the fitting of a protective helmet. CCD was suspected by the clinical geneticist. The family history identified no other members with bone abnormalities, delayed ossification or short stature.
Table 1 Clinical and radiological findings in $\operatorname{CCD}^{13}$

\begin{tabular}{|c|c|}
\hline Clinical & Radiological \\
\hline Skeletal & Skeletal \\
\hline Skull & Skull \\
\hline $\begin{array}{l}\text { Abnormally large, wide-open } \\
\text { fontanelles at birth }\end{array}$ & $\begin{array}{l}\text { Wide open sutures and patent } \\
\text { fontanelles }\end{array}$ \\
\hline $\begin{array}{l}\text { Delayed closure of the cranial } \\
\text { sutures }\end{array}$ & Wormian bones \\
\hline $\begin{array}{l}\text { Soft skull: calvaria dysplasia, } \\
\text { brachycephalic skull }\end{array}$ & Delayed ossification \\
\hline Midface hypoplasia & Hypoplasia of maxilla \\
\hline Frontal bossing & Segmental calvarial thickening \\
\hline Hypertelorism & Hypoplastic sinuses \\
\hline Thorax and shoulders & Thorax and shoulders \\
\hline $\begin{array}{l}\text { Clavicular hypoplasia: shoulders } \\
\text { brought to midline }\end{array}$ & $\begin{array}{l}\text { Complete absence, hypoplastic } \\
\text { clavicluae }\end{array}$ \\
\hline Respiratory distress on early age & $\begin{array}{l}\text { Cone-shaped thorax with narrow } \\
\text { upper diameter }\end{array}$ \\
\hline Increased mobility & Hypoplastic scapulae \\
\hline Hands & Hands \\
\hline Brachydactyly & $\begin{array}{l}\text { Deformed and short middle } \\
\text { phalanges }\end{array}$ \\
\hline Tapering fingers & Hypoplastic distal phalanges \\
\hline Short, broad thumbs & Long second metacarpal \\
\hline Spine & Spine \\
\hline Kyphosis & Hemivertebrae, posterior wedging \\
\hline Scoliosis & Spondylolysis, spondylolisthesis \\
\hline Pelvis and hips & Pelvis and hips \\
\hline Pelvic dysplasia & Hypoplasia of iliac wings \\
\hline Other orthopaedic & Widening of sacroiliac joints \\
\hline Pes planus, genu valgum & $\begin{array}{l}\text { Delayed ossification of pubic bone } \\
\text { Wide pubic symhysis }\end{array}$ \\
\hline \multicolumn{2}{|l|}{ Dentition } \\
\hline \multicolumn{2}{|l|}{ Supernumerary teeth } \\
\hline \multicolumn{2}{|l|}{ Eruption failure of permanent teeth } \\
\hline \multicolumn{2}{|l|}{ Normal deciduous dentition } \\
\hline \multicolumn{2}{|l|}{ Auditory } \\
\hline \multicolumn{2}{|l|}{ Recurrent ear infections } \\
\hline \multicolumn{2}{|l|}{ Partial hearing loss } \\
\hline \multicolumn{2}{|l|}{ Other } \\
\hline \multicolumn{2}{|l|}{ Submucous cleft palate } \\
\hline \multicolumn{2}{|l|}{ Osteopaenia } \\
\hline \multicolumn{2}{|l|}{ Short stature } \\
\hline Normal intelligence & \\
\hline
\end{tabular}




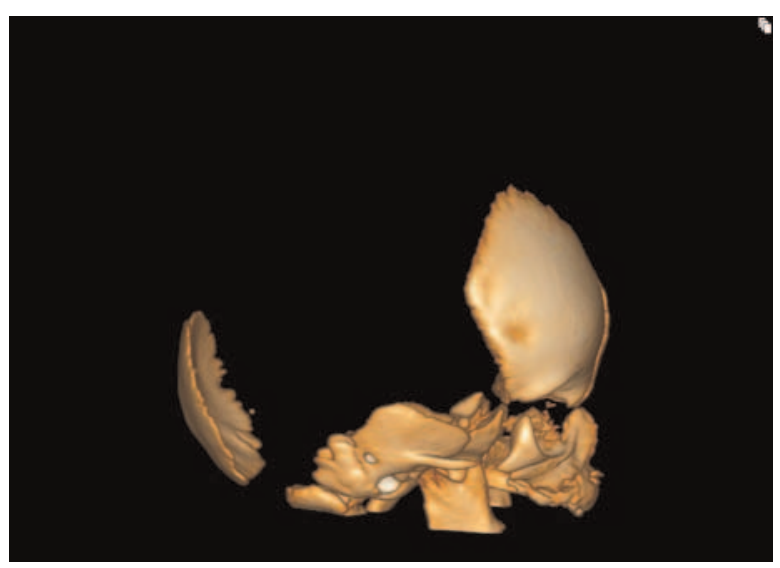

Figure 1 CT scan of the skull: Complete absence of ossification of both parietal bones in case 2 with CCD.

\section{INVESTIGATIONS}

Additional radiographic investigations showed complete aplasia of the right clavicle, a hypoplastic left clavicle, decreased/delayed ossification of the pubic bones and wide sacroiliac joints. DNA investigation of the RUNX2 gene identified a heterozygous nonsense mutation at nucleotide 1113 in exon 7.

\section{DIFFERENTIAL DIAGNOSIS}

The combination of hypoplastic clavicles and delayed closure of fontanelles were suggestive of CCD. Solitaire clavicular dysplasia or delayed closure of sutures is a rather non-specific sign. The combination of normal deciduous teeth, delayed eruption of permanent teeth and multiple impacted supernumerary teeth is practically diagnostic of CCD. However, a small number of other diagnosis can be considered. Delayed closure of fontanelles, Wormian bones, and hypoplastic clavicles are also features of pyknodysostosis, mandibuloacral dysplasia and Yunis-Varon syndrome. ${ }^{3}$ The finding of increased bone density (osteosclerosis, with risk of fractures) and dwarfism distinguishes pyknodysostosis from CCD.

Mandibuloacral dysplasia is characterised by progressive loss of bone from the distal phalanges. Yunis-Varon syndrome also features prenatal growth retardation, failure to thrive and limb malformations. Furthermore, this syndrome is usually lethal.

\section{OUTCOME AND FOLLOW-UP}

The child is currently 12 months of age and is doing well. Audiological evaluation was unremarkable. Orthopaedic and dental follow-up has been initiated. Radiographic evaluation of parietal bone formation will be performed in due time.

\section{DISCUSSION}

CCD is a rare autosomal-dominant skeletal dysplasia most prominently affecting bones derived from intramembranous ossification, such as the cranium and the clavicles. However, it is a generalised skeletal dysplasia, and can therefore affect the entire skeleton. ${ }^{1}{ }^{3}$ Common clinical and radiological findings are presented in table $1{ }^{2}$ However, the clinical presentation is heterogeneous even within families. Severe parietal bone dysplasia is very rare and only a few case reports have been described. ${ }^{4} 5$

In 1997, mutations in the RUNX2 gene were identified as the molecular aetiology. CCD is inherited in an autosomal-dominant manner or may result from new mutations in the gene. ${ }^{1} 3$ There is variable expression, clinical manifestations vary greatly between individuals with the same causative mutation. ${ }^{3}{ }^{4}$ RUNX2 is a transcription factor which controls the differentiation of bone. ${ }^{5}$ Sequence analysis of genomic DNA of the RUNX2 gene detects mutations in $60-70 \%$ of individuals with a clinical diagnosis of CCD. ${ }^{1}$ Many RUNX2 mutations are known, but no clear phenotype-genotype correlation has been established. ${ }^{5}$

In this case, DNA investigation of the RUNX2 gene identified a heterozygous nonsense mutation at nucleotide 1113 in exon 7. This mutation leads to premature termination of protein synthesis, affecting the C-terminal region of the resultant protein distal to the runt domain.

The common clinical and radiological findings of CCD are presented in table 1 . If a diagnosis of CCD is suspected, a complete diagnostic work-up (table 2) is recommended to confirm the diagnosis, tailor treatment and enable proper counselling. ${ }^{1}$

We will briefly discuss the potential symptoms and clinical course of CCD. Because the various aspects of the disease may become apparent at different stages during childhood and adolescence, long-term follow-up by different specialists is needed (table 3).

\section{Skeletal}

The suspicion of defects in skull mineralisation will need prompt identification and in the case of large defects protection with a helmet. With increasing age the un-ossified areas become smaller and true wormian bones develop, particularly around the lambdoid suture. ${ }^{3}$ Cardoso et $a l^{4}$ described a patient with severe parietal bone dysplasia at birth and spontaneous partial regrowth. Thoracic anomalies have been reported to cause respiratory distress in early infancy. ${ }^{3}$ Hypoplastic clavicles do not necessarily imply disability. The pelvis is invariably involved and results from a delay in ossification during adulthood. A dysplastic pelvis in pregnant women with CCD may explain the increased prevalence of caesarean section delivery. ${ }^{2}$

\section{Auditory/ear-nose-throat disorders}

Recurrent ear infections and hearing loss is prevalent in CCD due to maxilla-facial hypoplasia and underdeveloped ossicles. $^{2}{ }^{3}$ The incidence of submucous cleft palate is increased in CCD and individuals with CCD should thus be evaluated for this condition. ${ }^{23}$

Table 2 Diagnostic work up in CCD

Radiographic investigation: Anteroposterior (AP) and lateral projections of the skull $^{*}$ and thorax, AP of the pelvis, lateral of the lumbar spine and AP of the long bones, hands and feet.

Referral to cleft team if submucous cleft is present or suspected

Audiological screening

Molecular genetic testing

*If the cranial vault defect is significant, low-dose three-dimensional CT scan is recommended and the head needs protection with a helmet. 
Table 3 Recommendations for long-term follow-up by different specialists

\begin{tabular}{ll}
\hline Monitoring growth & $\begin{array}{l}\text { General } \\
\text { paediatrician }\end{array}$ \\
Monitoring for osteoporosis in early adolescence & General \\
(DEXA scan)_-general paediatrician & paediatrician \\
Dental evaluation & Dentist \\
Orthopaedic complications & Orthopaedic \\
Sinus and ear infections, audiometry, respiratory & surgeon \\
obstruction & ENT department* \\
Skull mineralisation & Craniofacial surgeon \\
& Rehabilitation \\
Genetic counselling & services \\
\hline *Ear Nose and Throat & Clinical geneticist \\
\hline
\end{tabular}

\section{Dentition}

Dental anomalies are common. Follow-up by a dentist should start at a young age. ${ }^{13}$

\section{Osteopaenia}

If there are clinical signs of osteopaenia (increased number of fractures), evaluation and treatment of osteoporosis should be started early. Otherwise, bone mineral density should be measured by dual photon x-ray absorption scan early in adolescence, and every 5-10 years thereafter. ${ }^{1}$

\section{Stature}

Final height is reduced in patients with $\mathrm{CCD} .{ }^{1-3}$ Length is usually normal at birth but height drops below or around the second centile between the ages of 4 and $8 .^{3}$ Males achieve an average final height of $165 \mathrm{~cm}( \pm 8 \mathrm{~cm})$, females $156 \mathrm{~cm}( \pm 10 \mathrm{~cm}) .{ }^{12}$

\section{Development}

Motor development may be slightly delayed (age of walking). In most cases, intellectual development is normal. ${ }^{2}$

If CCD is suspected prenatally by ultrasonographic findings of hypomineralisation or absence of skull bones, an elective caesarean section can be performed to prevent intracranial haemorrhage. ${ }^{4}$
Upon examination during labour, the skull is palpated as a soft presenting body and can be mistaken for a breech presentation.

Postnatal in individual patients with severe defects, the diagnosis of CCD will likely be made soon after birth. However, diagnosis may be delayed in mildly affected patients until, for example, dental anomalies become apparent. If CCD is suspected prenatally by ultrasonographic findings of hypomineralisation of skull bones, an elective caesarean section is recommended to prevent brain injury. $^{2}$

\section{Learning points}

- Cleidocranial dysplasia is an autosomal-dominant skeletal dysplasia affecting intramembranous ossification.

- Clinical characteristics are heterogeneous, ranging from mild dental abnormalities to more severe defects, such as complete absence of ossification of parietal bones.

- Long-term follow-up is needed by a multidisciplinary team as more symptoms can become apparent during growth and different stages of childhood.
Competing interests None.

Patient consent Obtained.

\section{REFERENCES}

1. Mendoza-Londono R, Lee B. Cleidocranial dysplasia 2006 Jan 03 [updated 2009 Jun 25]. In: Pagon RA, Bird TD, Dolan CR, et al., eds. Gene reviews [Internet]. Seattle, WA: University of Washington, Seattle, 1993. http://www. ncbi.nlm.nih.gov/bookshelf/br.fcgi?book= geneqpart =ccd

2. Cooper SC, Flaitz CM, Johnston DA, et al. A natural history of cleidocranial dysplasia. Am J Med Genet 2001;104:1-6.

3. Mundlos S. Cleidocranial dysplasia: clinical and molecular genetics. J Med Genet 1999;36:177-82.

4. Cardoso BM, Dupont J, Castanhinha S, et al. Cleidocranial dysplasia with severe parietal bone dysplasia: a new (p.Val124Serfs) RUNX2 mutation. Clin Dysmorphol 2010;19:150-2

5. Cunningham ML, Seto ML, Hing AV, et al. Cleidocranial dysplasia with severe parietal bone dysplasia: C terminal RUNX2 mutations. Birth Defect Res (Part A): Clin Mol Teratol 2006;76:78-85.

This pdf has been created automatically from the final edited text and images.

Copyright 2012 BMJ Publishing Group. All rights reserved. For permission to reuse any of this content visit http://group.bmj.com/group/rights-licensing/permissions.

BMJ Case Report Fellows may re-use this article for personal use and teaching without any further permission

Please cite this article as follows (you will need to access the article online to obtain the date of publication).

Broeks I, Veenstra-Knol IE, Kamps AWA. A rare presentation of cleidocranial dysplasia. BMJ Case Reports 2012;10.1136/bcr-03-2012-6101, Published XXX

Become a Fellow of BMJ Case Reports today and you can:

- Submit as many cases as you like

- Enjoy fast sympathetic peer review and rapid publication of accepted articles

- Access all the published articles

- Re-use any of the published material for personal use and teaching without further permission

For information on Institutional Fellowships contact consortiasales@bmjgroup.com

Visit casereports.bmj.com for more articles like this and to become a Fellow 